\title{
Perbandingan Kadar Heat Shock Protein 90 dan Tumor Necrosis Factor- $\alpha$ Antara Kehamilan Preterm Dengan Ketuban Pecah Dini dan Tanpa Ketuban Pecah Dini
}

\author{
Riri Karnain ${ }^{1}$, Yusrawati² $^{2}$ Erkadius $^{3}$
}

\begin{abstract}
Abstrak
Ketuban pecah dini (KPD) berkaitan dengan peningkatan kadar Heat Shock Protein 90 (HSP 90) dan Tumor Necrosis Factor- $\alpha$ (TNF- $\alpha$ ) yang muncul akibat stres oksidatif. Tujuan penelitian ini adalah membandingkan kadar HSP 90 dan TNF- $\alpha$ antara kehamilan preterm dengan KPD dan tanpa KPD. Penelitian ini menggunakan rancangan comparative study yang dilaksanakan di RSUD dr. Rasidin, RS Tk.III Reksodiwiryo, RS Bhayangkara, Puskesmas Lubuk Buaya dan Laboratorium Biomedik Fakultas Kedokteran Universitas Andalas dari bulan Oktober 2017 sampai Juli 2018. Jumlah sampel sebanyak 24 ibu hamil preterm dengan KPD dan 24 ibu hamil preterm tanpa KPD dengan menggunakan teknik consecutive sampling. Pemeriksaan HSP 90 dan TNF- $\alpha$ menggunakan metode ELISA. Uji normalitas data dengan uji Shapiro-Wilk. Analisis data komparatif menggunakan uji Mann-Whitney. Median kadar HSP 90 yaitu $11,21 \mathrm{ng} / \mathrm{mL}$ pada kehamilan preterm dengan $\mathrm{KPD}$ dan 9,15 $\mathrm{ng} / \mathrm{mL}$ pada kehamilan preterm tanpa KPD dengan nilai $p<0,05$. Median kadar TNF- $\alpha$ yaitu $0,21 \mathrm{ng} / \mathrm{mL}$ pada kehamilan preterm dengan KPD dan $0,17 \mathrm{ng} / \mathrm{mL}$ pada kehamilan preterm tanpa KPD dengan nilai $p<0,05$. Kadar HSP 90 dan TNF- $\alpha$ pada kehamilan preterm dengan KPD lebih tinggi secara bermakna dibandingkan pada kehamilan preterm tanpa KPD.
\end{abstract}

Kata kunci: Heat Shock Protein 90, Tumor Necrosis Factor- $\alpha$, Kehamilan Preterm Dengan KPD, Kehamilan Preterm Tanpa KPD

\begin{abstract}
Preterm premature rupture of membranes (PROM) is associated with an increase in levels of 90 Heat Shock Protein (HSP 90) and Tumor Necrosis Factor-a (TNF- $\alpha$ ) due to oxidative stress. The aim of this study was to compare HSP 90 and TNF- $\alpha$ levels between preterm pregnancy with and without PROM. Research design was used with a comparative study approach and was implemented at Dr Rasidin Provincial Public Hospital,, Reksodiwiryo Tertiary Hospital, Bhayangkara Hospital, Lubuk Buaya Health Center and the Biomedical Laboratory of the Faculty of Medicine, Andalas University from October 2017 to July 2018. The number of samples were 24 respondents had been diagnosed with PROM and 24 without PROM and were selected using a consecutive sampling technique. Examination of HSP 90 and TNF- $\alpha$ was conducted using ELISA. Mann-Whitney test was used to compare data between populations. The median level of HSP 90 was $11,21 \mathrm{ng} / \mathrm{mL}$ in preterm pregnancies with PROM and 9,15 $\mathrm{ng} / \mathrm{mL}$ in preterm pregnancies without PROM, a significant difference at the $p<0,05$ level. The median level of TNF- $\alpha$ is $0.21 \mathrm{ng} / \mathrm{mL}$ in preterm pregnancies with $P R O M$ and $0.17 \mathrm{ng} / \mathrm{mL}$ in preterm pregnancies without PROM a significant difference at the $p<0,05$ level. HSP 90 and TNF- $\alpha$ levels in preterm pregnancies with PROM were significantly higher than in preterm pregnancies without $P R O M$.
\end{abstract}

Keywords: Heat Shock Protein 90, Tumor Necrosis Factor- $\alpha$, PROM, Pregnancy Complications

Affiliasi penulis : 1. Program Studi S2 IImu Kebidanan Pascasarjana Fakultas Kedokteran Universitas Andalas Padang, 2. Sub Divisi Feto Maternal Bagian Obgyn Fakultas Kedokteran Universitas Andalas, 3.Bagian Fisiologi Fakultas Kedokteran Universitas Andalas Korespondensi : Riri Karnain : riri_karnain@yahoo.com Telp: 085274705505

\section{PENDAHULUAN}

Ketuban pecah dini (KPD) adalah pecahnya ketuban sebelum waktunya melahirkan/sebelum adanya tanda-tanda inpartu, yang dapat terjadi pada akhir kehamilan maupun jauh sebelum waktunya melahirkan. Bila ketuban pecah dini terjadi pada usia kehamilan < 37 minggu disebut ketuban pecah dini preterm. ${ }^{(1-3)} \mathrm{KPD}$ preterm masih merupakan masalah di dunia termasuk Indonesia dan memerlukan perhatian yang besar, karena prevalensinya yang cukup tinggi. Diketahui prevalensi KPD preterm di dunia adalah 3,0-4,5\% dari seluruh kehamilan. ${ }^{(4)} \mathrm{Di}$ RSUD dr. Rasidin Padang, pada tahun 2014 ditemukan kejadian KPD preterm sebanyak 24 kasus dari total persalinan, tahun 2015 menurun menjadi 19 kasus dari total persalinan, tahun 2016, sebanyak 20 kasus dari total persalinan, dan pada tahun 2017 kembali meningkat menjadi 25 kasus dari total persalinan. Dampak KPD preterm bagi ibu dan janin, misalnya pada ibu dapat menyebabkan infeksi (korioamnionitis), infeksi puerperalis, perdarahan post partum, serta dry-labor.(5) KPD preterm juga sangat berpengaruh terhadap janin, walaupun ibu belum 
menunjukkan infeksi tetapi janin mungkin sudah terkena infeksi karena infeksi intrauterin terjadi lebih dulu sebelum gejala pada ibu dirasakan. Selain itu, dapat terjadi hipoksia dan asfiksia sekunder, kompresi tali pusat, dll. Hal ini dapat meningkatkan morbiditas dan mortalitas maternal maupun perinatal (4) KPD preterm juga merupakan penyumbang 6-40\% persalinan preterm atau prematuritas. ${ }^{(4)}$ Penyebab ketuban pecah dini adalah multifaktorial. Menurut Manuaba, yang dapat menyebabkan KPD adalah ibu yang mengalami stres baik fisik, psikologis, maupun sosial. Salah satunya adalah stres oksidatif, yaitu ketidakseimbangan antara antioksidan dengan radikal bebas $^{(5)}$

Bila ada sel yang mengalami stress, maka akan menimbulkan respon stress yang berupa heat shock response (HSR). HSR diatur pada tingkat transkripsi oleh suatu mekanisme yang melibatkan heat shock transcription factor (HSF), terutama HSF-1. Peningkatan HSF-1 akan membantu dalam meningkatkan ekspresi HSP 70 dan HSP 90 yang telah terbentuk pada jumlah/kadar tertentu di dalam serum dan plasma darah. ${ }^{(6)}$

HSP 90 merupakan salah satu protein stres yang dominan diinduksi dalam sel. ${ }^{(7)}$ Pada saat sel mengalami stres, HSP 90 akan mengalami peningkatan ekspresi. ${ }^{(8)}$

HSP 90 mempunyai efek mempengaruhi proses transkripsi yang menghasilkan sitokin pro inflamasi, salah satunya Tumor Necrosis Factor- $\alpha$ (TNF- $\alpha)^{(9)}$ TNF- $\alpha$ merupakan sitokin utama pada respons inflamasi akut terhadap bakteri Gram-negatif dan mikroba lainnya. Tingginya kadar TNF dalam serum mempunyai hubungan dengan aktivitas atau prognosis berbagai penyakit infeksi. ${ }^{(10)}$

TNF- $\alpha$ dan sitokin pro inflamasi yang lain berperan dalam menstimulasi aktivitas dari uterus dan proses pematangan serviks dengan jalan memproduksi prostaglandin, kortisol, dan mendegradasi matriks ekstraseluler dari selaput ketuban melalui jalur matrix metalloproteinase (MMP). Aktifitas dari degradasi kolagen terutama dipengaruhi oleh MMP, yang dihambat oleh inhibitor jaringan yang spesifik (Tissue Inhibitors Of Metalloproteinase/TiMP). Pecahnya membran ketuban juga dapat disebabkan oleh ketidakseimbangan antara MMP dan TiMP, yang menyebabkan degradasi matriks ekstraseluler membran ketuban.(11) Pada studi ini akan diteliti secara biomolekuler khususnya hubungan kadar HSP 90 dan TNF- $\alpha$ dengan kejadian KPD.

\section{METODE}

Rancangan penelitian yaitu observasional dengan pendekatan comparative study yang dilaksanakan di RSUD dr. Rasidin, RS Tk.III Reksodiwiryo, RS Bhayangkara, Puskesmas Lubuk Buaya dan Laboratorium Biomedik Fakultas Kedokteran Universitas Andalas pada bulan Oktober 2017- Juli 2018.
Populasi penelitian ini adalah ibu hamil dengan usia kehamilan 28-34 minggu dengan diagnosis KPD dan tanpa KPD. Sampel penelitian berjumlah 24 responden ibu hamil preterm dengan KPD dan 24 responden ibu hamil preterm tanpa KPD dengan menggunakan teknik consecutive sampling.

Kriteria inklusi pada penelitian ini adalah janin hidup, tunggal, letak normal, usia kehamilan 28-34 minggu, terdiagnosis hamil preterm dengan KPD dan tanpa KPD berdasarkan hasil rekam medis, tidak ada tanda-tanda inpartu, tidak ada plasenta previa/solusio plasenta, tidak menderita diabetes mellitus, anemia, hipertensi dalam kehamilan, preeklampsi/eklampsi, tidak ada tanda-tanda overdistensi uterus, tidak mengalami inkompetensia serviks, tidak ada polihidramnion, tidak ada infeksi genitalia dan bersedia menjadi responden.

Kriteria ekslusi pada penelitian ini adalah ibu hamil yang sebelumnya sudah ditetapkan menjadi sampel, tetapi saat pengambilan darah, pembuluh darah sulit untuk ditentukan dan menolak menjadi responden.

Ibu hamil preterm yang telah didiagnosis oleh dokter/residen yang memenuhi kriteria inklusi dan ekslusi di tempat penelitian dijadikan sampel penelitian, selanjutnya diberikan penjelasan tentang penelitian ini, begitu juga dengan keluarganya. Setelah mengerti dan bersedia menjadi sampel, pasien diminta menandatangani informed consent. Identitas dan hasil pemeriksaan klinis dicatat pada formulir pengumpulan data. Kemudian dilakukan pengambilan sampel darah vena sebanyak $\pm 3 \mathrm{ml}$ oleh petugas labor yang sedang bertugas saat itu, setelah itu masukkan kedalam tabung centrifuge (vacuum tube) tanpa EDTA. Letakkan darah yang ada di dalam vacuum tube pada rak tabung,, selanjutnya didiamkan selama 10-20 menit pada suhu ruangan sampai darah membeku. Kemudian melakukan centrifuge sampel darah dengan kecepatan 2000-3000 rotasi per menit (rpm) selama 20 menit, setelah itu ambil serum dari hasil centrifuge menggunakan micropipete, masukkan ke dalam microtube yang sudah diberi kode sesuai dengan identitas subjek penelitian. Selanjutnya sampel serum dikirim ke Laboratorium Biomedik FK-UNAND menggunakan cooler bag untuk disimpan di dalam lemari pendingin (suhu $-80^{\circ} \mathrm{C}$ ). Pengukuran serum dilakukan setelah seluruh jumlah sampel terpenuhi. Kemudian dilakukan pemeriksaan HSP 90 dan TNF- $\alpha$ menggunakan metode ELISA.

Uji normalitas data dilakukan dengan menggunakan uji Shapiro-Wilk. Untuk melihat perbandingan pada variabel dilakukan uji MannWhitney (data tidak terdistribusi normal). Semua data yang diperoleh diolah dengan menggunakan program komputer.

\section{HASIL}

Karakteristik responden pada penelitian ini akan ditampilkan pada Tabel 1, 2, dan 3. Peneliti tidak menemukan hubungan yang bermakna antara riwayat 
KPD dengan kehamilan preterm dengan KPD dan tanpa KPD. Peneliti juga tidak menemukan perbedaan yang bermakna antara paritas dan usia ibu hamil preterm dengan KPD dan tanpa KPD. Dapat disimpulkan bahwa ketiga karakteristik tersebut tidak mempengaruhi kejadian ketuban pecah dini pada penelitian ini.

Berdasarkan hasil analisa statistik, didapatkan bahwa median kadar serum HSP 90 dan TNF- $\alpha$ pada kehamilan preterm dengan KPD lebih tinggi dibandingkan dengan kehamilan preterm tanpa KPD. Hasil uji statistik juga menunjukkan terdapat perbedaan yang bermakna antara kadar serum HSP 90 dan TNF- $\alpha$ pada kehamilan preterm dengan KPD dan tanpa KPD $(p<0,05)$ (Tabel 4).

Tabel 1. Karakteristik responden penelitian berdasarkan riwayat KPD pada kehamilan preterm dengan KPD dan tanpa KPD

\begin{tabular}{lccccc}
\hline Karakteristik & \multicolumn{2}{c}{ KPD } & \multicolumn{2}{c}{ Tanpa } & \\
& \multicolumn{2}{c}{$\mathbf{n = 2 4}$} & \multicolumn{2}{c}{$\begin{array}{c}\mathbf{n}=\mathbf{2 4} \\
\mathbf{f}=\end{array}$} & Fisher \\
& $\mathbf{f}$ & $\mathbf{\%}$ & $\mathbf{f}$ & $\mathbf{\%}$ & \\
\hline Riwayat KPD & & & & & 0,097 \\
Ada & 6 & 25 & 1 & 4,2 & \\
Tidak ada & 18 & 75 & 23 & 95,8 & \\
\hline
\end{tabular}

Berdasarkan Tabel 1 dapat dilihat bahwa tidak terdapat hubungan yang bermakna antara riwayat KPD pada kehamilan preterm dengan KPD dan tanpa KPD.

Tabel 2. Karakteristik responden penelitian berdasarkan usia pada kehamilan preterm dengan KPD dan tanpa KPD

\begin{tabular}{cccc}
\hline Kelompok & $\mathbf{n}$ & $\begin{array}{c}\text { Usia } \\
\text { Responden } \\
\text { Rerata } \pm S D\end{array}$ & $\boldsymbol{p}$ \\
\hline KPD & 24 & $30,4 \pm 5,4$ & \\
Tanpa KPD & 24 & $29,9 \pm 6,3$ & 0,770 \\
\hline
\end{tabular}

Berdasarkan Tabel 2 dapat diketahui bahwa terhadap variabel usia responden, rerata usia pada responden dengan KPD lebih tinggi $(30,4 \pm 5,4)$ dibandingkan dengan usia responden tanpa KPD $(29,9 \pm 6,3)$. Hasil uji statistik menunjukkan tidak terdapat perbedaan yang bermakna antara usia ibu hamil preterm dengan KPD dan tanpa KPD $(p>0,05)$.

Tabel 3. Karakteristik responden penelitian berdasarkan paritas pada kehamilan preterm dengan KPD dan tanpa KPD

\begin{tabular}{cccc}
\hline Kelompok & $\mathbf{n}$ & $\begin{array}{c}\text { Paritas } \\
\text { Median } \\
\text { (Min - Maks) }\end{array}$ & $\boldsymbol{p}$ \\
\hline KPD & 24 & $2,0(1-5)$ & \\
$\begin{array}{c}\text { Tanpa } \\
\text { KPD }\end{array}$ & 24 & $2,0(1-7)$ & 0,772 \\
\hline
\end{tabular}

Berdasarkan Tabel 3 dapat diketahui bahwa terhadap variabel paritas, median paritas responden dengan KPD dan tanpa KPD adalah 2,0. Hasil uji statistik menunjukkan tidak terdapat perbedaan yang bermakna antara paritas ibu hamil preterm dengan KPD dan tanpa KPD $(p>0,05)$.

Tabel 4. Perbandingan Kadar Serum HSP 90 dan TNF- $\alpha$ Antara Kehamilan Preterm dengan KPD dan tanpa KPD

\begin{tabular}{|c|c|c|c|c|c|}
\hline$\underset{\mathbf{k}}{\text { Kelompo }}$ & $\mathbf{n}$ & $\begin{array}{c}\text { HSP 90 } \\
\text { (ng/mL } \\
\text { ) } \\
\text { Median } \\
\text { (Min - } \\
\text { Maks) }\end{array}$ & $p$ & $\begin{array}{c}\text { TNF- } \alpha \\
\text { (ng/mL) } \\
\text { Median } \\
\text { (Min - } \\
\text { Maks) }\end{array}$ & $p$ \\
\hline KPD & 24 & $\begin{array}{c}11,21 \\
(8,79- \\
45,68)\end{array}$ & 0,000 & $\begin{array}{c}0,21 \\
(0,11- \\
0,54)\end{array}$ & 0,015 \\
\hline $\begin{array}{c}\text { Tanpa } \\
\text { KPD }\end{array}$ & 24 & $\begin{array}{c}9,15 \\
(5,69- \\
10,61)\end{array}$ & & $\begin{array}{c}0,17 \\
(0,12- \\
0,24)\end{array}$ & \\
\hline
\end{tabular}

Ket: Uji Mann-Whitney

Pada Tabel 4 dapat diketahui bahwa median kadar serum HSP 90 dan TNF- $\alpha$ pada kehamilan preterm dengan KPD lebih tinggi dibandingkan dengan kehamilan preterm tanpa KPD. Hasil uji statistik juga menunjukkan terdapat perbedaan yang bermakna antara median kadar serum HSP 90 dan TNF- $\alpha$ pada kehamilan preterm dengan KPD dan tanpa KPD $(p<$ 0,05).

\section{PEMBAHASAN}

Peningkatan kadar serum HSP 90 terjadi karena adanya stressor. Salah satunya adalah stres oksidatif, yang terjadi akibat ketidakseimbangan antara radikal bebas dengan antioksidan. ${ }^{(12)}$ Sumber radikal bebas dari dalam tubuh misalnya dari proses oksidasi dan olahraga yang berlebihan, peradangan akibat menderita sakit kronik dan stres, sedangkan dari luar tubuh radikal bebas dapat diperoleh melalui proses merokok/terpapar asap rokok, terpapar udara yang tercemar, radiasi fototerapi (penyinaran), konsumsi obat-obatan termasuk kemoterapi, pestisida dan zat kimia lainnya. ${ }^{(13)}$

Bila ada sel yang mengalami stres, maka mekanisme pertahanan tubuh terhadap stres adalah heat shock response (HSR). HSR diatur pada tingkat transkripsi oleh suatu mekanisme yang melibatkan heat shock transcription factor (HSF). Pada manusia ditemukan 3 jenis gen HSF, yaitu HSF-1, HSF-2, dan HSF-4. Yang paling berperan dalam modulasi HSR adalah HSF-1. Peningkatan HSF-1 akan membantu dalam meningkatkan ekspresi HSP 90 yang telah terbentuk pada jumlah/kadar tertentu di dalam serum dan plasma darah. ${ }^{(6)}$

Dengan adanya peningkatan dari HSP 90, sehingga mempengaruhi proses transkripsi yang menghasilkan sitokin proinflamasi seperti Interleukin$1 \beta$ (IL-1 $\beta)$, IL-6, IL-8, dan Tumor Necrosis Factor- $\alpha$ $(\mathrm{TNF}-\alpha) \cdot{ }^{(9)}$

TNF- $\alpha$ merupakan sitokin utama pada respons inflamasi akut terhadap bakteri negatif-Gram dan 
mikroba lainnya. Tingginya kadar TNF dalam serum mempunyai hubungan dengan aktivitas atau prognosis berbagai penyakit infeksi. ${ }^{(10)}$

Pengeluaran sitokin pro inflamasi ini dapat meningkatkan ekspresi matrix metalloproteinase (MMP) pada korion, desidua dan serviks, sehingga terjadi peningkatan degradasi kolagen. Aktifitas dari degradasi kolagen terutama dipengaruhi oleh MMP, yang dihambat oleh jaringan inhibitor jaringan yang spesifik (TiMP). Pecahnya membran ketuban juga dapat disebabkan oleh ketidakseimbangan antara MMP dan TiMP, yang menyebabkan degradasi matriks ekstraseluler membran ketuban. Hal inilah yang menyebabkan terjadinya pecah ketuban. ${ }^{(11)}$

Pengeluaran sitokin pro inflamasi juga akan merangsang pengeluaran bahan baku asam arakhidonat, kemudian asam arakhidonat akan dikonversi menjadi prostaglandin oleh siklooksigenase II menjadi prostaglandin. Prostaglandin akan menimbulkan rangsangan pada otot uterus sehingga terjadi kontraksi. Hal ini menyebabkan adanya perubahan dan pembukaan serviks, dan pecahnya selaput ketuban. ${ }^{(14)}$

\section{SIMPULAN}

Median kadar HSP 90 dan TNF- $\alpha$ pada kehamilan preterm dengan KPD lebih tinggi secara bermakna dibandingkan pada kehamilan preterm tanpa KPD.

\section{UCAPAN TERIMA KASIH}

Terima kasih kepada semua pihak atas bimbingan, bantuan, dan motivasi dalam penelitian ini serta semua pihak lainnya yang telah memberikan kontribusi dalam pelaksanaan penelitian ini.

\section{DAFTAR PUSTAKA}

1. Prawirohardjo S. Buku Acuan Pelayanan Kesehatan Maternal dan Neonatal. Jakarta: Yayasan Bina Pustaka; 2010. p. 286-287

2. Nugroho T. Patologi Kebidanan. Yogyakarta: Nuha Medika; 2012. p.150-151.

3. Cunningham FG, Leveno KJ, Bloom SL, Spong CY, Dashe JS, Hoffman BL, et al. Williams Obstetrics. 24th ed. Jakarta: EGC; 2014. p. 246, 274-276, 283, 515, 517, 781.

4. Mercer BM. Preterm Premature Rupture of Membrane. In R.Creasy RK, Creasy \& Resnik's Maternal-Fetal Medicine. Saunders Elsevier. 2010; 101(1):178-193. URL:

https://www.perinatology.theclinics.com. (diunduh 18 Januari 2016).

5. Manuaba IBG. IImu Kebidanan, Penyakit Kandungan dan Keluarga Berencana. Jakarta: EGC; 2010. p. 165, 167-169, 173-174, 177, 243, 281, 283-285.

6. Baird NA, Turnbull DW, Johnson EA. Induction of the Heat Shock Pathway During Hypoxia
Requires Regulation of Heat Shock Factor by Hypoxia-Inducible Factor-1. J Biol Chem. 2006;281(50):38675-81. URL : https://m.jbc.org (diunduh 2 Maret 2016).

7. Sun JX, Liao JK. Induction of angiogenesis by heat shock protein 90 mediated by protein kinase Akt dan endothelial nictric oxide synthase. Arterioscler Thromb Vasc Biol. 2004; 24(12):2238-2244. URL: https://www.ahajournals.org (diunduh 12 April 2016).

8. Nollen EAA, Morimoto RI. Chaperone Signaling Pathway. Molecular Chaperones as Stresssensing Heat Shock Protein. Journal of Cell Science. 2002;115(14):2809-16. URL : http://jcs.biologists.org/content/115/14/2809.articl e-info (diunduh 25 November 2015).

9. Padmini E, Venkatraman U, Lavanya S. Effect of HSP70 and 90 in Modulation of JNK, ERK Expression in Preeclamptic Placenta Endothelial Cell. Cell Biochem Biophys. 2012;64(3):187-95. URL:https://www.ncbi.nlm.nih.gov/m/pubmed/226 89214/ (diunduh 15 Januari 2016).

10. Lockwood CJ, Arcuri F, Toti P, Felice CD, Krikun G, Guller S, et al. Tumor Necrosis Factor and Interleukin-1 regulate Interleukin-8 Expression in Third Trimester Decidual Cell Implications for the Genesis of Chorioamnionitis. Am J Pathol. 2006;169(4):1294-1302. URL : https://www.ncbi.nlm.nih.gov/m/pubmed/1700348 6 (diunduh 29 Mei 2016).

11. Hackenhaar AA, Albernaz EP, Fonseca TMV da. Preterm premature rupture of the fetal membranes: association with sociodemographic factors and maternal genitourinary infections. Jornal de Pediatria. 2014;90(2):197-202. URL : https://www.ncbi.nlm.nih.gov/m/pubmed/2418430 0/ (diunduh 16 September 2016).

12. Valko M, Leibfritz D, Moncol J, Cronin MTD, Mazur M, Telser J. Free Radicals and Antioxidants in Normal Physiological Functions and Human Diseases. Int $\mathrm{J}$ Biochem Cell Biol. 2007;39(1):44-84.

URL:https://www.ncbi.nlm.nih.gov/m/pubmed/169 78905/ (diunduh 03 Juni 2016).

13. Tapan E. Kanker, Antioksidan dan Terapi Komplementer. Jakarta: Elex Media Komputindo; 2005. p.103-104, 187-195.

14. Vanderhoeven JP, Bierle CJ, Kapur RP, McAdams RM, Beyer RP, Bammler TK. Group B streptococcal infection of the choriodecidua induces dysfunction of the cytokeratin network in amniotic ephitelium: a pathway to membrane weakening. PLoS Pathogens. 2014;10(3): 283284. URL :

https://journals.plos.org/plospathogens/article/co mments?id=10.1371/journal.ppat. 1003920 (diunduh 30 Mei 2016). 